\title{
Union Influence on Wage and Change in Employment Rate in an Overlapping Generations Economy
}

\author{
Toyoki Matsue ${ }^{1,2}$ \\ ${ }^{1}$ Faculty of Economics, International University of Kagoshima, Kagoshima, Japan \\ ${ }^{2}$ Graduate School of Economics, Kobe University, Kobe, Japan \\ Email: t-matsue@eco.iuk.ac.jp
}

How to cite this paper: Matsue, T. (2018) Union Influence on Wage and Change in Employment Rate in an Overlapping Generations Economy. Theoretical Economics Letters, 8, 2733-2740. https://doi.org/10.4236/tel.2018.812172

Received: May 18, 2018

Accepted: September 16, 2018

Published: September 19, 2018

Copyright $\odot 2018$ by author and Scientific Research Publishing Inc. This work is licensed under the Creative Commons Attribution International License (CC BY 4.0).

http://creativecommons.org/licenses/by/4.0/

\section{c) (i) Open Access}

\begin{abstract}
The effect of labor market institutions on the unemployment rate has been widely studied in macroeconomic dynamics. Union influence is one of the most important issues in the labor market institutions. Thus, this study investigates the effects of union influence on wages with regard to employment dynamics using an overlapping generations model with closed economy. We assume a wage setting equation that is discussed in the existing literature and we consider an economy in which unemployment exists. The model shows that high upward pressure on wages leads to low employment rates not only in the steady state but also on the equilibrium path.
\end{abstract}

\section{Keywords}

Employment Dynamics, Unions, Unemployment Insurance, Overlapping Generations Model

\section{Introduction}

The relationship between labor market institutions and unemployment has been researched in many studies. Nickell [1], Blanchard and Wolfers [2], and Nickell et al. [3] analyze how labor market institutions affect unemployment rates. Faccini and Bondibene [4] and Gnocchi et al. [5] investigate a relationship between some labor market institutions and cyclical behavior of unemployment rates for OECD countries. Union influence is one of the most important issues in the labor market institutions. Layard et al. [6] discuss the importance of trade unions in the European labor market, in which the union membership ratio and coverage ratio are proxy variables for influence of trade union on wage setting or un- 
ion power. ${ }^{1}$ The OECD [7] shows that the union membership ratio recently has been declining in European countries, whereas the union coverage ratio is still high. ${ }^{2}$ Gregg et al. [10] point out that rising unemployment and declining trade union influence have reduced wage pressure, leading to wage growth among middle to high earners in the UK after 1979.

Union influence has been discussed in the macroeconomic literature too. Bräuninger [11], Corneo and Marquardt [12], Josten [13], and Ono [14] study union influence on unemployment (employment) using overlapping generations models. Corneo and Marquardt [12] and Ono [14] assume a monopoly union that sets two targets: high wage, and low rate of unemployment (high rate of employment). Corneo and Marquardt [12] indicate that increasing union preferences for a high wage increases the unemployment rate.

In this study, we consider an overlapping generations economy and assume a wage-setting equation that is discussed in Blanchard [15]. The wage-setting equation is an increasing function of the employment rate. Moreover, the equation has a parameter that expresses an upward pressure on wage. Then, we can focus on the effect of union influence on wage for employment dynamics. This study shows that high upward pressure on wage brings low employment rates not only in the steady state but also on the equilibrium path.

The rest of this paper is organized as follows. Section 2 sets up the overlapping generations model with unemployment. Section 3 discusses the property of the equilibrium. Section 4 investigates the relationship between union influence and employment rate. Section 5 concludes.

\section{The Model}

Let us consider an overlapping generations closed economy. We assume that the population does not grow and a new generation is born in each period. The size of the labor force in each period is $N$. The model structure is illustrated in Figure 1. The economy consists of firms and individuals. The firms employ labor and capital to produce the final good. In the labor market, we assume the wage-setting equation to analyze the union influence on wage. In this model, the individuals can either be employed or unemployed in their youth. The unemployment insurance plays a role as the transfer from employment to unemployment.

\subsection{Firms}

We assume that the final good $Y_{t}$ is produced by competitive firms that have a constant-return-to-scale Cobb-Douglas production function:

$$
Y_{t}=\left(A L_{t}\right)^{\alpha} K_{t}^{1-\alpha},
$$

\footnotetext{
${ }^{1}$ The union membership ratio is the percentage of workers who belong to a union, and the union coverage ratio is the proportion of workers who are covered by bargaining agreements.

${ }^{2}$ Booth [8] points out that the coverage ratio is a better measure of union influence than the union membership ratio is. Machin [9] also indicates that the union coverage ratio could be a better measure of union influence.
} 


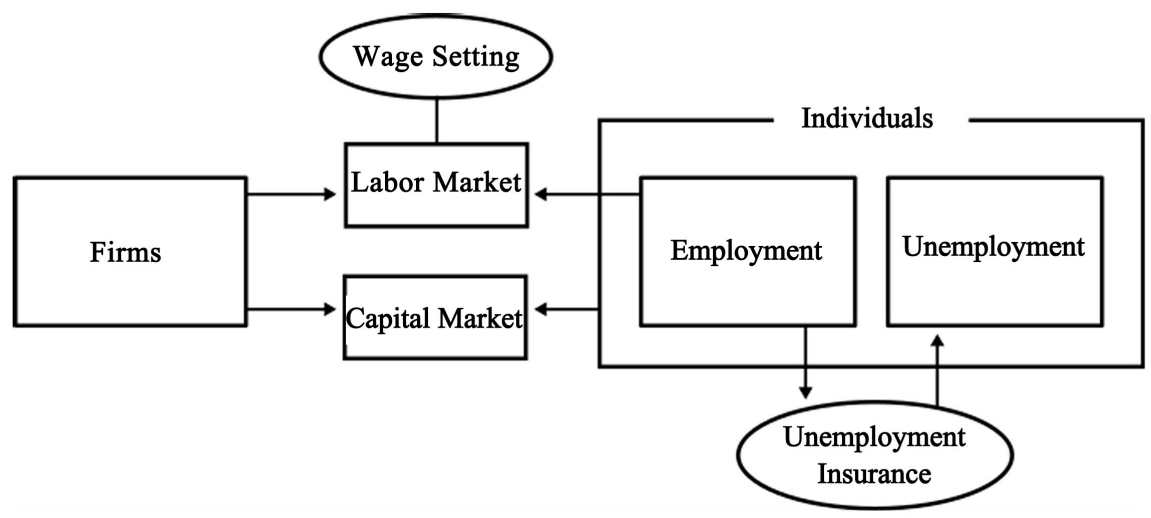

Figure 1. The model structure. Source: Author drawing.

where $0<\alpha<1, A>0$ is productivity, $L_{t}$ is labor, $A L_{t}$ is efficient labor, and $K_{t}$ is capital. Suppose that firms have no adjustment cost for labor adjustment and investment. As discussed in Ono [14], labor and capital are chosen by a firm so as to maximize its current profit because there is no intertemporal element in the firms' maximization problem under this assumption:

$$
\pi_{t}=\left(A L_{t}\right)^{\alpha} K_{t}^{1-\alpha}-w_{t} L_{t}-R_{t} K_{t},
$$

where $w_{t}$ is the wage and $R_{t}$ is the rental price of capital.

The first-order conditions for profit maximization are as follows.

$$
\begin{gathered}
L_{t}: w_{t}=\alpha A l_{t}^{\alpha-1}, \\
K_{t}: R_{t}=(1-\alpha) l_{t}^{\alpha},
\end{gathered}
$$

where $l_{t} \equiv\left(A L_{t} / K_{t}\right)$. Equations (1) and (2) express that firms hire labor until the marginal product of labor equals the wage and firms choose capital equal to the rental price of capital.

\subsection{Wage Setting}

Similar to Blanchard [15], we suppose that the wage-setting equation is as follows:

$$
w_{t}=\theta\left(\frac{L_{t}}{N}\right)^{\gamma},
$$

where $\theta$ is wage at zero unemployment, $\gamma \geq 1$ is wage elasticity with respect to the employment rate, and $N$ is the labor force in this economy, which is assumed constant. The increase in $\theta$ exerts upward pressure on the wage. Blanchflower and Bryson [16] and Nickell [1] point out that the union puts upward pressure on the wage rate. Although there are many ways to interpret the increase in $\theta$, we interpret it as union influence on wage in this study. Equation (3) is transformed as follows:

$$
w_{t}=\theta\left(\frac{l_{t}}{l_{t}^{N}}\right)^{\gamma},
$$


where $l_{t}^{N} \equiv\left(A N / K_{t}\right)$. Substitute Equation (4) into Equation (1), and then we obtain the following:

$$
l_{t}=\left(\frac{\alpha A}{\theta}\right)^{\frac{1}{1-\alpha+\gamma}}\left(l_{t}^{N}\right)^{\frac{\gamma}{1-\alpha+\gamma}} .
$$

In addition, combining Equations (1) and (3), the employment ratio is expressed as follows:

$$
\frac{L_{t}}{N}=\left(\frac{\alpha A l_{t}^{\alpha-1}}{\theta}\right)^{\frac{1}{\gamma}} .
$$

Then, we can consider the unemployment rate $1-\left(L_{t} / N\right)$.

\subsection{Individuals}

Individuals supply one unit of labor in youth. The lifetime utility of an agent born at $t U_{t}^{i}$ is defined over youth consumption $c_{1 t}^{i}$ and old-age consumption $c_{2 t+1}^{i}$ :

$$
U_{t}^{i}=\ln c_{1 t}^{i}+\beta \ln c_{2 t+1}^{i}, \quad i=e, u,
$$

where $0<\beta<1$ is a discount factor. The individuals can either be employed or unemployed: $i=e$ if an individual is employed in youth, and $i=u$ if he/she is unemployed in youth.

The budget constraints of an individual born at $t$ are as follows:

$$
\begin{gathered}
x(1-\phi) w_{t}+(1-x) u_{t}=c_{1 t}^{i}+s_{t}^{i}, \\
R_{t+1} s_{t}^{i}=c_{2 t+1}^{i},
\end{gathered}
$$

where $x=1$ if he/she is employed, $x=0$ if he/she is unemployed, $u_{t}$ is the youth unemployment benefit, $s_{t}^{i}$ is savings, and $\phi$ is the contribution to unemployment insurance.

Individuals maximize Equation (7) subject to Equations (8) and (9). Then, the savings are given by

$$
\begin{gathered}
s_{t}^{e}=\frac{\beta(1-\phi)}{1+\beta} w_{t}, \\
s_{t}^{u}=\frac{\beta}{1+\beta} u_{t} .
\end{gathered}
$$

If the wage is high, then the savings of employment are high. In addition, if the unemployment insurance is high, then the savings of unemployment are high.

We assume that unemployment insurance is the transfer from employment to unemployment, which is balanced in each period:

$$
\left(N-L_{t}\right) u_{t}=\phi w_{t} L_{t}
$$

where the left-hand side is the sum of the unemployment benefit and the right-hand side is the sum of the transfer. 


\section{Equilibrium}

We investigate the property of the equilibrium in this section. The capital market clearing is as follows:

$$
K_{t+1}=s_{t}^{e} L_{t}+s_{t}^{u}\left(N-L_{t}\right) .
$$

Substitute Equations (10) and (11) into Equation (13).

$$
K_{t+1}=\frac{\beta(1-\phi)}{1+\beta} w_{t} L_{t}+\frac{\beta}{(1+\beta)} u_{t}\left(N-L_{t}\right) .
$$

Substitute Equations (1) and (12) into (14):

$$
K_{t+1}=\frac{\alpha \beta}{1+\beta} l_{t}^{\alpha} K_{t} .
$$

From Equations (5) and (15), the dynamics of $l_{t}$ are given by

$$
l_{t+1}=\left(\frac{1+\beta}{\alpha \beta}\right)^{\frac{\gamma}{1-\alpha+\gamma}} \frac{(1-\alpha)(1+\gamma)}{l_{t}^{\frac{1-\alpha+\gamma}{2}}},
$$

where $0<[(1-\alpha)(1+\gamma) /(1-\alpha+\gamma)]<1$. $^{3}$ The equilibrium is characterized by Equation (16) and initial condition $l_{0}$. Then, the dynamics of $l_{t}$ are independent of the effect of union influence on wage $\theta$, because the effect of $\theta$ at period $t$ and $t+1$ offset each other. From Equations (10) and (11), the increase in $\beta$ leads to an increase in the savings rate. Therefore, as shown in Equation (16), the increase in $\beta$ causes the efficient labor per unit of capital to decline.

The dynamics of $l_{t}$ is illustrated in Figure 2. We represent in the plane $\left\{l_{t}, l_{t+1}\right\}$ the curve $l_{t+1}=g\left(l_{t}\right)$, where

$g\left(l_{t}\right) \equiv[(1+\beta) / \alpha \beta]^{\{\gamma /(1-\alpha+\gamma)\}} l_{t}^{\{(1-\alpha)(1+\gamma) /(1-\alpha+\gamma)\}}$. The steady state is given by the intersections with the $45^{\circ}$ line, which is globally stable. Then, the steady state value of efficient labor per unit of capital $l^{*}$ is as follows:

$$
l^{*}=\left(\frac{1+\beta}{\alpha \beta}\right)^{\frac{1}{\alpha}} .
$$

\section{Employment Dynamics}

In this section, we analyze the effect of a change in upward pressure on wage by running simulation. The parameter values are shown in Table 1. Similar to de la Croix and Michel [17], we assume that $\alpha=0.3$ and $\beta=0.3$. Suppose that a quarterly discount factor is 0.99 and one period equals 30 years; then we could set the discount factor as $0.99^{120} \approx 0.3$. The parameters $\gamma=1.0$ and $\theta=0.35$ are the same values used in Blanchard [15]. Moreover, the productivity level $A$ is chosen by having the employment rate $\left(L^{*} / N\right)=0.90$ in the steady state when $\theta=0.35$. From Equation (6), the steady state value of the employment ratio is expressed as $\left(L^{*} / N\right)=\left(\alpha A l^{*} \alpha-1 / \theta\right)^{1 / \gamma}$. Combining the steady state value of the ${ }^{3}$ From $0<1-\alpha<1$ and $1+\gamma>1$, we obtain $(1-\alpha)(1+\gamma)>0$. Furthermore, from $0<\alpha<1$ and $\gamma \geq 1$, we have $1-\alpha+\gamma>0$. Then, the fraction is positive. In addition,

$(1-\alpha)(1+\gamma)-(1-\alpha+\gamma)=-\alpha \gamma<0$. Therefore, we have $0<[(1-\alpha)(1+\gamma) /(1-\alpha+\gamma)]<1$. 
employment ratio and Equation (17), we obtain $A=\left[\theta / \alpha\left(L^{*} / N\right)^{\gamma}\{(1+\beta) / \alpha \beta\}^{\{(1-\alpha) / \alpha\}}\right]$. Substitute $\left(L^{*} / N\right)=0.90, \quad \theta=0.35$ and other parameter values into this equation; then, the productivity level is obtained. ${ }^{4}$ In the simulation, we assume $l_{0}=7000$.

In Figure 3(a), the solid line expresses the dynamics of $l_{t}$, while the dotted line shows the steady state value of $l_{t} . l_{t}$ is independent of the effect of union

Table 1. Parameters.

\begin{tabular}{ll}
\hline$\alpha$ Parameter in production function & 0.3 \\
$\beta$ Discount factor & 0.3 \\
$\gamma$ Elasticity of wage with respect to employment rate & 1.0 \\
$\theta$ Wage at zero unemployment & $0.35,0.40$, or 0.45. \\
$N$ Labor force & 1.0
\end{tabular}

Source: Blanchard [10], de la Croix and Michel [13], and Author's calculations.

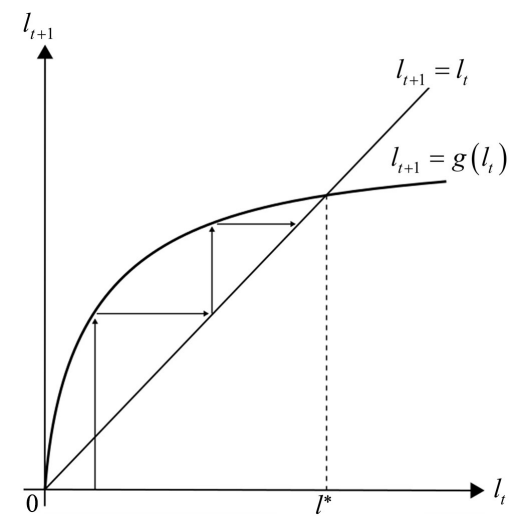

Figure 2. The dynamics of $l_{t}$. Source: Author drawing.

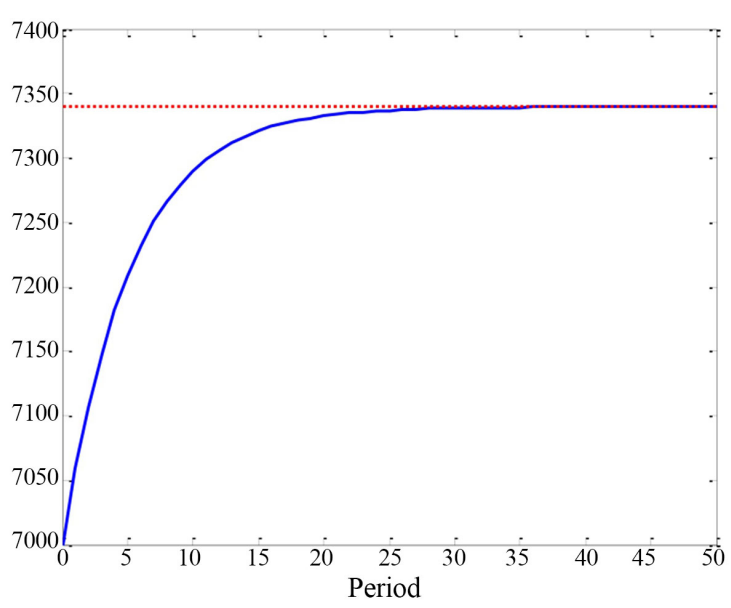

(a)

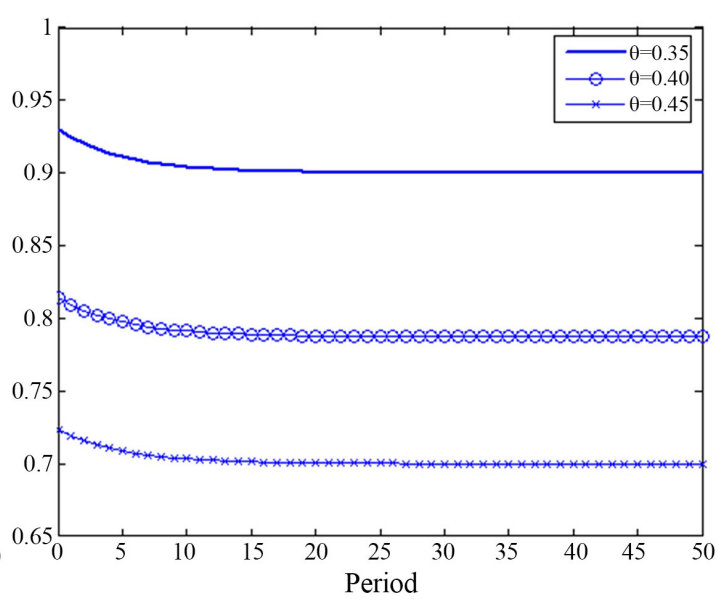

(b)

Figure 3. The change in union influence. Source: Author's computations. (a) The behavior of $l_{t}$; (b) The employment rate $\left(L_{t} / N\right)$ dynamics.

${ }^{4}$ The steady state value of employment rates $\left(L^{*} / N\right)$ for each value of upward pressure on wage $\theta$ is as follows: $\left(L^{*} / N\right)=0.90$ if $\theta=0.35,\left(L^{*} / N\right)=0.7875$ if $\theta=0.40$, and $\left(L^{*} / N\right)=0.70$ if $\theta=0.45$. 
influence on wage. Figure 3(b) expresses the relationship between upward pressure on wage and employment rate. The simulation results show that the high upward pressure on wage brings low employment rates, not only in the steady state but also on the equilibrium path.

Proposition

Suppose that upward pressure on wage is high; then, the employment rate is low, not only in the steady state but also on the equilibrium path.

\section{Concluding Remarks}

The effect of labor market institutions on the unemployment rate has been widely studied in macroeconomic dynamics. This study investigates the effect of union influence on wage for employment dynamics using an overlapping generations model, and shows that high upward pressure on wage brings low employment rates not only in the steady state but also on the equilibrium path.

The study could be extended by, for example, generalizing the utility function and production function. Moreover, the model could be extended to consider the firms' contribution rate to unemployment insurance. Further research of these issues remains to be under taken.

\section{Conflicts of Interest}

The author declares no conflicts of interest regarding the publication of this paper.

\section{References}

[1] Nickell, S. (1997) Unemployment and Labor Market Rigidities: Europe versus North America. Journal of Economic Perspectives, 11, 55-74. https://doi.org/10.1257/jep.11.3.55

[2] Blanchard, O. and Wolfers, J. (2000) The Role of Shocks and Institutions in the Rise of European Unemployment: the Aggregate Evidence. Economic Journal, 110, C1-C33. https://doi.org/10.1111/1468-0297.00518

[3] Nickell, S., Nunziata, L. and Ochel, W. (2005) Unemployment in the OECD since the 1960s. What Do We Know? Economic Journal, 115, 1-27.

https://doi.org/10.1111/j.1468-0297.2004.00958.x

[4] Faccini, R. and Bondibene, C.R. (2012) Labour Market Institutions and Unemployment Volatility: Evidence from OECD Countries. Bank of England Working Paper No. 461, London, 45.

[5] Gnocchi, S., Lagerborg, A. and Pappa, E. (2015) Do Labor Market Institutions Matter for Business Cycles? Journal of Economic Dynamics \& Control, 51, 299-317. https://doi.org/10.1016/j.jedc.2014.10.005

[6] Layard, R., Nickell, S. and Jackman, R. (2005) Unemployment: Macroeconomic Performance and the Labour Market. Oxford University Press, New York. https://doi.org/10.1093/acprof:oso/9780199279166.001.0001

[7] OECD (2015) Economic Policy Reforms 2015: Going for Growth. OECD Publishing, Paris.

[8] Booth, A.L. (2014) Wage Determination and Imperfect Competition. Labour Eco- 
nomics, 30, 53-58. https://doi.org/10.1016/j.labeco.2014.06.010

[9] Machin, S. (2000) Union Decline in Britain. British Journal of Industrial Relations, 38, 631-645. https://doi.org/10.1111/1467-8543.00183

[10] Gregg, P., Machin, S., and Fernández-Salgado, M. (2014) Real Wage and Unemployment in the Big Squeeze. Economic Journal, 124, 408-432. https://doi.org/10.1111/ecoj.12139

[11] Bräuninger, M. (2000) Wage Bargaining, Unemployment, and Growth. Journal of Institutional and Theoretical Economics, 156, 646-660.

[12] Corneo, G. and Marquardt, M. (2000) Public Pensions, Unemployment Insurance, and Growth. Journal of Public Economics, 75, 293-311. https://doi.org/10.1016/S0047-2727(99)00058-4

[13] Josten, S.D. (2006) Dynamic Fiscal Policies and Unemployment in a Simple Endogenous Growth Model. International Tax and Public Finance, 13, 701-716. https://doi.org/10.1007/s10797-006-6603-5

[14] Ono, T. (2007) Unemployment Dynamics in an OLG Economy with Public Pensions. Economic Theory, 33, 549-577. https://doi.org/10.1007/s00199-006-0150-2

[15] Blanchard, O.J. (1997) The Medium Run. Brooking Papers on Economic Activity, 2, 89-158. https://doi.org/10.2307/2534687

[16] Blanchflower, D.G. and Bryson, A. (2002) Changes over Time in Union Relative Wage Effects in the UK and the US Revisited. NBER Working Paper No. 9395, Cambridge.

[17] de la Croix, D. and Michel, P. (2002) A Theory of Economic Growth: Dynamics and Policy in Overlapping Generations. Cambridge University Press, New York. https://doi.org/10.1017/CBO9780511606434 